\section{Textbook of Gene Therapy}

Just over 15 years ago, the first viral vectors, based mainly on retroviruses, appeared on the scene. Few fields of biology have captured the imagination of the public, clinicians, biotechnology and big pharmaceutical companies as

\section{Opioids in Pain Control}

much as the promise of gene therapy. Mercifully for those of us practicing the science of gene therapy-or more accurately, gene delivery-'functional genomics' has become the new 'darling' and has removed some of the unwanted attention that was forced on us.

Therefore I was excited, though a bit surprised, to discover this Textbook of Gene Therapy. Unfortunately, this is not a textbook in the classical sense of a scholarly textbook of biochemistry or organic chemistry. Professor K.K. Jain has put together a series of monographs written for industrial readers and embellished them with superficial information on almost every disease or delivery system mentioned in
K. K. Jain

Textbook of

Gene Therapy

\author{
BASIC AND CLINICAL ASPECTS \\ Edited by Christoph Stein \\ Cambridge University Press, $\$ 95.00,359$ pp. \\ ISBN :0521622697, 1999 \\ Reviewed by Allan Basbaum \\ Department of Anatomy \\ W.M. Keck Foundation Center for \\ Integrative Neuroscience, University of \\ California San Francisco \\ 513 Parnassus Ave., Box 0452 \\ San Francisco, CA 94143 \\ email: aib@phy.ucsf.edu
}

In November 1989, Jean Marie Besson and I organized a Dahlem Conference meeting in Berlin, "Towards a New Pharmacotherapy of Pain: Beyond M orphine." However, after a week of discussion, we were forced to drop "Beyond M orphine" from thebook that ensued. Although the supposedly immovable Berlin Wall came down during themeeting, morphine'sdomination of the field of pain control remains. It is still the drug of choice for severe pain. Thus, Christoph Stein's book Opioids in Pain Control: Basicand Clinical Aspects, which provides up-to-date reviews of the basic science and clinical use of opioidsfor pain control, isstill needed and welcome.

The first eight chapters address the basic mechanisms through which opioids regulate pain. In addition to the traditional discussions of peripheral, spinal and supraspinal circuits through which opioids

operate, thereareinteresting reviews of topics that are covered less extensively in other books. The book includes reviews of themolecular biology of opioid receptors, enkephalin-degrading enzymes (with some heavy going chemistry), anti-opioid substances, basic mechanisms of opioid toleranceand theuse of transplants (such as endorphin-secreting adrenal chomaffin cells) for the treatment of pain. Thechapters are generally well-written; however, cross-referencing by the editor would have helped to integrateissues acrosschapters. For example, discussion of anti-opioid peptides (such as cholecystokinin) appears in several chapters, but apparently obliviousto oneanother.

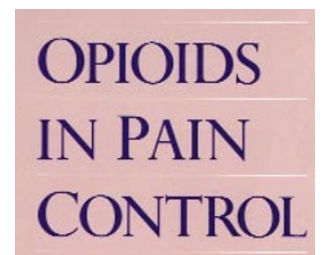

Basic and Clinical Aspects

Christoph Stein

connection with gene therapy. The book has nearly 400 pages and 29 chapters ranging from 2 pages on gene therapy of liver disorders to 50 pages for gene therapy of neurological disorders! I am puzzled as to the intended audience of this book. It is too thin in content for undergraduate, graduate students, or postdoctoral fellows, and too broad and uncritical for practicing physicians. Nor does it have enough information to guide a venture capitalist investing in gene therapy companies. Textbook of Gene Therapy is 'a mile wide and a millimeter deep' and should have been entitled Soundbites on Gene Therapy or, better yet, Smorgasbord of Gene Therapy.
The rest of the book consists of ten chapters on the clinical use of opioids to treat pain. Several chapters address the 'what, where and how much to inject' questions, for acute pain, non-malignant pain, intraoperative pain, and so on. These chapters will be of interest to all clinicians who treat pain. Two chapters stand out as being particularly well-written-these discuss the clinical pharmacology and adverse effects of opioids and the use of patient-controlled analgesia. By and large, all theclinical chaptersarefor clinicians; only two of them (on pre-emptive analgesia and visceral pain) refer heavily to basic science issues.

Although this book is mostly very comprehensive and up-to-date, somethings are missing. To understand how opioids regulatethetransmission of 'pain' messages, one must first understand how pain is generated. Where do opioid receptors fit into the pain transmission circuitry? Instead of beginning thebook with what isan excellent review of the molecular biology of opioid receptors, I would have begun with a review of the anatomy, physiology and pharmacology of pain mechanisms, something to which individual chapters could then refer. Also, the segregation of basic science and clinical issues, although understandable, is not ideal. At times I wished that certain clinical issues were better integrated into the basic science discussion-particularly the discussion of spinal opioids, a major topic that, surprisingly, did not get itsown chapter. Instead, spinal opioids aretreated in several of theclinical chapters, most extensively in theconcluding chapter on the use of opioids in obstetrics.

I also would have preferred a more comprehensive discussion of the opioid resistance of neuropathic pain, a question that is of great interest to basic scientists and clinicians. Further, the excellent chapter on mechanisms of opioid tolerance is not matched by an appropriatediscussion of the clinical problem. How prevalent istolerance to theanal gesic effects of opioids in patients, and istolerancemore problematic when opioids are used for cancer pain than for non- 